\title{
The Unethical Practice of Omitting Language in State Science Standards: Denying Students True Democratic Freedom
}

\author{
Annie Noel Wildes*
}

* University of Oklahoma

Jeannine Rainbolt College of Education, Norman, Oklahoma, USA.

E-mail: anniewildes@ou.edu

\section{Article Info}

Received: April 17, 2020

Revised: May 11, 2020

Accepted: May 16, 2020

\section{$10.46303 / j c s r .02 .01 .7$}

This is an Open Access article distributed under the terms of the CC BY-NC-ND 4.0 International license.

(https://creativecommons.org/licenses/bync-nd/4.0)

\section{How to cite}

Wildes, A. N. (2020). The unethical practice of omitting language in state science standards: Denying students true democratic freedom. Journal of Curriculum Studies Research, 2(1), 112-128.

\begin{abstract}
Climate change due to global warming is impacting the natural environment and humanity. Yet, legislators in states whose economies are in oil production, a major contributor of carbon dioxide emissions through the combustion of fossil fuels, continue to reject the evidence. Legislators go as far to say these findings are "hyperbole" and teaching such ideas would influence young students to a one sided argument. Legislators, through bills and resolutions rejecting such language in state science academic standards, deny students access to equitable science education opportunities. I submit this denial is unethical. It denies students opportunities to analyze and develop solutions to a problem that jeopardizes their future and generations to come. I use the frameworks of Karl Marx and Antonio Gramsci to identify the underlying causes of this problem. Understanding the underlying causes of the problem provides educators with a clearer vision of our responsibilities to act in providing equitable science education for our students. KEYWORDS

Science education; global warming; equity.
\end{abstract}




\section{A CALL FOR CLIMATE CHANGE EDUCATION IN SCHOOLS}

A human ecology is an imperative need. One of our political and economic priorities must be to adopt in every way a manner of life that respects the environment and supports the research in and use of forms of energy that preserve the patrimony of creation and are safe for human beings. (Benedict XVI, 2014, p. 73)

Nature and human life on this earth is in perilous danger of becoming extinct if we continue to deny our impact on the environment and do not accept our responsibility to preserve it for generations to come. According to the Fourth National Climate Assessment, "humanity's effects on the Earth system, through the large-scale combustion of fossil fuels and widespread deforestation and the resulting release of carbon dioxide (CO2) into the atmosphere...is unprecedented" (Weubbles et al., 2017, p. 23). In the last year, we have witnessed climate change as never before.

Antarctica experienced its hottest days on record between February 4 and 13, 2020. During that one event, $20 \%$ of the seasonal snow accumulation on Eagle Island melted. This is a typical seasonal snow melt for Alaska and Greenland, but not for Antarctica. Scientists report these events are happening more frequently in Antarctica (NASA, n.d.). Furthermore, Antarctica's glacial melting contributes to $20-25 \%$ of global sea-level rise (NASA, 2019). Although not occurring uniformly, sea-level rise is a threat to all coastlines around the world. Since 1880, the sea-level has risen 8 inches with 3 of these inches since 1993 (Global Change, n.d.). In the United States, cities such as Boston, Seattle, Miami, and New York are concerned about rising sea levels and are working on solutions such as sea walls to protect the cities (Greenblatt, 2017; Wallace-Wells, 2020). An area experiencing profound effects of global sealevel rise is Bangladesh (McDonnell, 2019).

Bangladesh has a long history of experiencing floods; however, in recent years, flooding has become a greater issue causing effects on wildlife, geography, and humanity (McDonnell, 2019). Climate change has increased torrential rainstorms and glacier melt that leads to devastating flooding, but a greater problem lies in global sea-level rise. As the sea erodes the coastline, homes and rice fields are being swallowed up. An increased salinity in freshwater renders it unfit for crops, livestock, and humans. These effects have caused an increase of migration to inland cities such as Dhak. Up to 400,000 low-income immigrants come to Dhak each year. Without suitable resources to support this increase in population, extreme poverty, health hazards, sex trafficking, and other risks have increased. Climate change has become a humanitarian crisis (McDonnell, 2019).

Australia is also experiencing the effects of climate change. In recent years, Australia has experienced its hottest and driest summers on record. Researchers have ascribed climate change as the cause for the devastating Australian bushfires in early 2020 (Gill, 2020). These 
fires, that burned for over four months, destroyed a quarter of the forests in Australia and effected over a billion of its wildlife.

The United States is also experiencing extremes in weather patterns fluctuating from warmer temperatures causing longer drought conditions to heavy rainfall in a shorter span of time (Weubbles et al., 2017). Narrowing the scope to Oklahoma, we find the effects of climate change. In recent years, Oklahoma has experienced more days of drought, especially in the north west corner of the state, and heavier precipitation in the east (Environmental Protection Agency, 2016; Greenblat, 2017; Oklahoma Climatological Survey, 2020). In March 2020, Oklahoma experienced a four degree increase in average daily high temperatures, with a surprising 100-degree day for Hollis, Oklahoma (Oklahoma Climatological Survey, 2020).

For decades, world policy leaders and advocacy groups have called for environmental protection policies and action to minimize the forthcoming effects of global warming and climate change. Recognized global leaders, such as Catholic popes from the last quarter of the 20th century, have addressed the moral and ethical responsibilities of humans to care for the earth. Pope Benedict XVI and Pope Francis have been considered the most radical papal environmental advocates in the 21st century (Burton, 2014). In his Encyclical letter, Laudato si': On Care for our Common Home (2015), Pope Francis stated:

the climate is a common good, belonging to all and meant for all.... Humanity is called to recognize the need for changes of lifestyle, production and consumption in order to combat this warming or at least the human causes which produces or aggravate it....Climate change is a global problem with grave implications: environmental, social, economic, political, and for the distribution of goods.... Our lack of response to these tragedies involving our brothers and sisters points to the loss of that sense of responsibility for our fellow men and women upon which all civil society is founded. (pp. 18-20)

Science is necessary to understand the nature of our environmental problem and to develop solutions to promote change. To this end, both Pope Benedict XVI and Pope Francis acknowledge and welcome scientific research. They have spoken with scientists to understand how the effects of the combustion of fossil fuels has led to global warming (Benedict XVI, 2014; Francis, 2015). Pope Benedict XVI (2014) most earnestly praised scientific advancements, but urged scientists "should always be informed by the imperatives of fraternity and peace, helping to solve the great problems of humanity" (pp. 123-124).

In 2012, the National Research Council (NRC) restructured science education through the creation of A Framework for K-12 Science Education: Practices, Crosscutting Concepts, and Core Ideas. The development of A Framework sought not only to increase students' interests in science, technology, engineering, and mathematics (STEM) careers, but also to provide equitable access of science education for all students (NRC, 2012). The aim of science education is to promote a science literate citizenry: 
being a critical consumer of information about science and engineering requires the ability to read or view reports of scientific or technological advances or applications (whether found in the press, the Internet, or in a town meeting) and to recognize the salient ideas, identify sources of error and methodological flaws (Next Generation Science Standards [NGSS] Lead States, 2013, Appendix F, p. 15)

The unfortunate truth for American students is that not all students are receiving equitable access to current scientific evidence in their science classes. With certain agendas in place, students are denied opportunities to question and analyze data on how human activities, such as the combustion of fossil fuels, effect climate change.

After the NRC (2012) released A Framework, national science standards were created. The Next Generation Science Standards: For States, By States (2013) were developed to help educators teach science in K-12 grades. Currently, 19 states, along with the District of Columbia, have adopted the NGSS, and 21 states have adapted the NGSS. Recognizing the emergent need for global warming and climate change education, the NGSS includes a sixth-grade middle school performance expectation that explicitly addresses the causes of global warming: MS-ESS3-5: "ask questions to clarify evidence of the factors that have caused the rise in global temperatures" (NGSS Lead States, 2013, p. 71). The performance expectation's clarification statement reads: "examples of factors include human activities (such as fossil fuel combustion, cement production, and agricultural activity)" (NGSS Lead States, 2013, p. 71).

In 2014, the Oklahoma State Board of Education unanimously voted to approve the new Oklahoma Academic Standards for Science (OAS-S) that were adapted from the NGSS. However, when the OAS-S appeared before the House Administrative Rules and Government Insight Committee, there was opposition from House representatives. Former Republican state representative Mark McCoullough questioned the language of "Earth and Human Activity" in Earth and Space Science standards (Halter, 2019; Mooney, 2014). He stated, "there's been a lot of recent criticisms in some sectors as to what some consider hyperbole related to climate change" (Halter, 2019; Mooney, 2014). He was concerned these standards would "inculcate into some pretty young impressionable minds a fairly one-sided view as to that controversial subject" (Halter, 2019, para. 11). The committee voted 10-1 to reject the OAS-S, but the standards were eventually passed by the Oklahoma House and Senate. While the OAS-S passed, the NGSS MS-ESS3-5, explicitly addressing global warming, was not adopted in the OAS-S for middle school.

The adaption of the NGSS for Wyoming's science standards in 2016 also faced criticism from legislators. Republican state representative Matt Teeters led the way to reject the NGSS. He felt the standards regarding the impact of human activities, such as the combustion of fossil fuels, were "over emphasized, almost activism within the curriculum" (Edwards, 2017, para. 6). To this end, Teeters sponsored a footnote to the bill that blocked considering any parts of NGSS found in the proposed Wyoming science standards. Wyoming's State Board of Education, after 
holding hearing sessions to understand what Wyomingites wanted, revised the science standards to soften climate change language. Wyoming did adapt the NGSS MS-ESS3-5 standard; however, the performance expectation's clarification statement did not include "factors of human activities such as the combustion of fossil fuels."

\section{THE PROBLEM WITH DENYING EQUITABLE SCIENCE EDUCATION IN CLIMATE CHANGE}

These examples of legislators pressing for omitting certain language regarding the impacts of human activities on global warming and climate change poses a moral and ethical dilemma. In a country that values democratic freedoms, the pursuit of life, liberty, and happiness, denying our students access to this scientific knowledge limits students' access to these promises. Only true democratic freedom comes from having the knowledge to act when action is needed (Greene, 1988). There are four problems that affect our students and educators when equitable science education is denied: (a) limits quality science literacy, (b) limits students' response and action towards the humanitarian crisis global warming creates, (c) denies students autonomy and providing value to society, and (e) denies educator autonomy as intellectual professionals in their field.

First, denying equitable science education as it pertains to global warming and climate change limits quality science literacy for students in these states that helps them become critical consumers of science. Without the opportunity to analyze scientific evidence that the combustion of fossil fuels has caused an increase in global temperatures, students are denied a stake in the game to make a positive change. The lack of this science knowledge denies students equal opportunities to compete with students in other states towards the development of solutions to a catastrophic problem. As educators, we have an ethical and moral responsibility to provide our children with equitable educational opportunities to build a better future for themselves.

Second, the humanitarian crisis in Bangladesh is an ethical and moral imperative for us. As educators, we have a responsibility to help students develop their moral and ethical character (Siefert \& Sutton, 2011). For this reason, we need to include the impacts of global warming on the social aspects of humanity. Students have a right to be involved in the conversation regarding the social justice ramifications of climate change. In Pope Francis's (2015) encyclical letter, he stated, "young people demand change. They wonder how anyone can claim to be building a better future without thinking of the environment crisis and the sufferings of the excluded" (p. 12).

Third, Paulo Freire (1998) called for educators to take on "a point of view that favors the 'autonomy of the student'” (p. 21). Limiting this scientific knowledge sends a message to our young students that we do not value them as contributors to society. When former Oklahoma state representative Mark McCullough concluded young minds would be "inculcated" with a "one-sided argument," he had, in effect, dehumanized both our educators and our young 
students. Middle school students are just entering an age when they can begin to hypothesize about world issues. They question injustices occurring in our society and want to develop solutions. These young students aspire to be part of the conversation and have their voices heard. When a student's autonomy is recognized by the teacher, they become engaged in learning (Seifert \& Sutton, 2011).

Lastly, in addition to denying student autonomy, educators' autonomy as intellectual professionals in their field was diminished. Educators have been prepared with extensive knowledge in child cognitive development, pedagogy, and curriculum design. They are aware of their students' needs. The community of science educators who developed the NGSS did so in a way that reflects the cognitive progress of K-12 students. Science educators thought middle school students were ready to take on the challenge of human activities causing global warming and climate change. Legislators, with less understanding of instruction and curriculum, exerted their power to limit what teachers could and could not teach by voting against them in committees or adding footnotes to defund the NGSS.

\section{UNDERSTANDING THE UNDERLYING CAUSES OF THE PROBLEM}

There are multiple causes for legislators in these states to omit language in science standards that suggests human activities, such as the combustion of fossil fuels, has led to global warming and climate change. Regarding this, it is essential to identify the constructs of these states. A litany of constructs could be at work, but for the purpose of this paper, the economic base, political, and religious affiliations will be examined in the state of Oklahoma.

If anyone on the streets of America is randomly asked about Oklahoma's economics, politics, and religious affiliations, the likely response would be "oil, conservative republicans, and protestants." According to economic statistics and surveys, they would be right (Chen, 2019; Di Piero, 2015; Pew Research Center 2014, 2019; Stebbins, 2018). Each of these constructs needs further evaluation determining how it affects decisions on what can and cannot be taught. More than that, identifying the root causes will provide explanations of why people act in the manner they do and how to stop the perpetuation of these actions that denies equitable science education.

\section{Economics}

Capitalism runs deep in America. In a 2019 Pew Research Center survey regarding positive or negative views of capitalism and socialism, $65 \%$ of Americans had positive views of capitalism while only $42 \%$ had positive views of socialism. Among Republicans or Republican-leaning Independents, $68 \%$ had stronger positive views of capitalism and only negative views of socialism. Interestingly, among Democrats and Democrat-leaning Independents, 38\% presented with both positive and negative views of capitalism and socialism. The major themes of capitalism that emerged were the arguments that capitalism advances American's economic 
strength, America was established under capitalism, and capitalism is essential for maintaining individual freedoms (Pew Research Center, 2019).

Oklahoma's top five industries in 2015 were energy, information and finance, transportation and distribution, agriculture and biosciences, and aerospace and defense (Di Piero, 2015). Many of these industries can be linked directly to energy because energy is needed for them to function. Oklahoma frequently makes the top 10 list of oil producing states in America, having come in at number 6 in 2019 (Chen, 2019). Up to 20\% of jobs in Oklahoma are tied to oil and gas (Di Piero, 2015). The oil and gas industry brings in $\$ 24.3$ billion (14\%) of the gross domestic profit (GDP) for the state. Aside from real estate, the largest industries in other states only bring in 6\% of their GDP (Stebbins, 2018). The billions of dollars pumped into the state is just one aspect of the oil and gas industry's role influencing legislative decision making. Between January 2015 and March 2017, the oil and gas industry contributed $\$ 683,000$ to political campaigns in Oklahoma with most going to Republican candidates (Brown, 2017). Considering the standard concerning the combustion of fossil fuels, it becomes evident why state representative McCullough eluded to these claims as hyperbole (Mooney, 2014; Halter, 2019). These legislators would be wise to promote the oil and gas industry in Oklahoma's legislative laws, policies, and resolutions. In this case, the House Administrative Rules and Government Insight Committee's rejection of the OAS-S reflected the relationship between the oil and gas industry, and legislators.

The issue is the mode of production, that is the relationship of the economic base and the superstructures it creates. The theory of modes of production was born out of Karl Marx's criticism of industrial capitalists (Marx, 1887/2010). Marx claimed the goal of a capitalist was two-fold. First, the capitalist aims to produce a commodity that could be sold, also known as a use-value. In addition, the capitalist seeks to produce a surplus-value, that is, a profit outside the costs of materials and labor (Marx, 1887/2010). As previously discussed, the economic base valued in America and believed to provide the economic strength of America is capitalism.

To begin the discussion on the capitalistic mode of production, it is essential to understand the historic relationship between capitalism and the natural environment. Europe became a successful colonizing power over other civilizations because Europeans increased their production (Crosby, 1986/2018). Crosby (1986/2018) claimed increasing production could only "be accomplished by exploiting the ecosystems, mineral resources, and human assets of whole continents outside the lands of the society" (p. xviii). This ecological imperialism brought in growth, wealth, and power that continues today with the oil and gas industries.

An aspect of Marx's (1887/2010) criticisms of capitalism is how the capitalist views the natural environment (land, wind, water, minerals, and lumber) as belonging to themself for the use in the production of goods. Though not directly part of the argument on global warming, the oil and gas industries' profits are derived from the products produced from the exploitation 
of natural oil and gas reserves. In turn, the combustion of fossil fuels, the product of these natural resources, produces $\mathrm{CO}_{2}$ emissions.

In addition to the concerns for the natural environment, Marx was critical of the relationship between the capitalist and the worker in the base of production. In Capital, Marx (1887/2010) stated, "the laborer works for the capitalist instead of for himself" (p. 86). The laborer, therefore, must depend upon the capitalist for work to provide the necessities of food and shelter. Both the products produced by the laborer and the laborer become, in a sense, property of the capitalist. This relationship further influences societies' culture, political power, and institutions.

Marx's (1887/2010) criticisms of capitalism, at the time, were of the widening class division created by the Industrial Revolution taking place in Europe. The increase in production was fueling the capitalist's ambition to create more wealth for themself. Laurent (2020) definition of $21^{\text {st }}$ century capitalism reflects Marx's viewpoints:

the regime of "salariat" (wage earning via employment contract), the reign of finance, and to borrow from the Marxist repertoire, an exploitation of workers by shareholders, this latter feature being the key contemporary driver of both human well-being and environmental degradations. (p. 156)

Returning to the oil and gas industry in Oklahoma, it is clear to see the relationship between the capitalistic mode of production and the superstructure as impacting decisions of its people to omit language in science standards. With the industry providing $20 \%$ of jobs in Oklahoma, the workforce is dependent upon the industry for its livelihood (Di Piero, 2015). Recognizing that the combustion of fossil fuels as a contributor to global warming could potentially put people out of work if the oil and gas industry folded due to demands of alternative energies. This not only influences the worker's actions in terms of support for the gas and oil industry, but also of the political power base. If a state dependent upon $14 \%$ of the GDP the oil and gas industry contributes to the economy were to allow language in science standards that suggests the combustion of fossil fuels contributes to global warming and climate change, the state would be committing economic suicide. For the preservation of employment and state income, politicians would be wise to control what can and cannot be taught in its public-school system concerning the combustion of fossil fuels.

In addition, the oil and gas industry has subliminally sent messages to residents and visitors that oil is big business. Upon approaching Oklahoma City, one sees the Devon Energy Tower, one of several big oil firms, from miles away. The skyscraper beckons people to visit the top floor to get a bird's eye view of Oklahoma (Devon, n.d.). Nestled between the interstates that serve as America's heart of commercial intersection is the Chesapeake Energy Arena, another large oil firm (Chesapeake Energy, 2019). If a person were to attend an Oklahoma City Thunder NBA game, coincidentally at the Chesapeake Energy Arena, this person would see the Love's Travel Stops and Country Stores' logo prominently displayed on the players' jerseys (National 
Basketball Association, n.d.). In 2019, Love's was \#17 on Forbes America's Largest Private Companies, with their major source of income from fuel sales (Forbes, 2019). Finally, when one visits Oklahoma's state capitol, one would see the world's only capitol to be surrounded by working oil wells (Oklahoma State Legislature, n.d.). The oil and gas industry has subverted itself into the culture. Without knowledge, society replicates the economic base of capitalism by supporting these seemingly innocuous entertainment and tourist venues.

\section{Politics and Religion}

While Marx focused on the economic base as being the power that drives society, Antonio Gramsci also recognized other organizational aspects of society as having power over those in lower position (Ives, 2004). Hegemony, the domination of one power over another, is frequently attributed to Gramsci; however, the term was used as far back as ancient times to mean military coercion and power (Ives, 2004). For Gramsci, according to Ives (2004), forms of hegemony take place when the dominating culture manipulates the consent of the people in such a way the people accept it as natural. Without a clue, the people have given consent to becoming subjects of this dominant power (Ives, 2004). In the case of Oklahoma, in addition to the mode of production, political and religious affiliations also hold power over its people.

To understand how political affiliation dominates the culture in Oklahoma, it is essential to understand Oklahoma's political history. Since 1968, Oklahoma has voted for a Republican presidential candidate and has had a domineering presence in the U. S. Senate and House of Representatives (Gaddie, n.d.). In 2019, Republicans accounted for $47 \%$ of registered voters in the state (Oklahoma State Election Board, 2019). Interestingly, Oklahoma did not start out as a Republican state. Yet, despite Oklahoma's early political dominance of Democrats and Socialists, the state has always been conservative according to Bob Blackburn, Oklahoma Historical Society's executive director (Krehbiel, 2016). Contrary to our modern-day definition of a "Democratic liberal," early Oklahoma Democrats were conservative. They held different beliefs than that of the country's Democrats and Socialists. Having strong agrarian values, Oklahoma Democrats and Socialists were against any government control. Furthermore, they were not interested in collectivism, but personal economic opportunity. The Oklahoma Democrats and Socialists held conservative values and as such voted for conservative politicians who would create conservative policies (Goble, n.d.). Over time, the nation's Democratic party grew less in line with Oklahoma political beliefs. As such, the political conservative value won out, and the Republican party, fitting the bill, came into dominance.

Oklahoma continues to be staunchly conservative Republican. Whatever policies and agendas an incumbent Democrat president pushes will not be met with friendly acceptance. Case in point, during the committee hearing over the OAS-S, McCoullough referred to the standard language, "Earth and Human activity," as echoing the president's recent statements (Mooney, 2014). The president at the time was President Barack Obama who had created the 
Climate Action Plan (CAP) that called for policies to decrease carbon emissions, increase the use of alternative energy vehicles in both government agencies and public transportation, and push down the reliance on fossil fuels to name a few (Environmental and Energy Institute, 2015). This political hegemony has dictated what can and cannot be taught in Oklahoma schools.

Religion and politics are closely intertwined in Oklahoma because of its deep southern historical roots. In the early part of Oklahoma's history, when Democrats and Socialists were dominating, the belief was "one could not call himself a Christian...if he was not a socialist, too" (Krehbiel, 2016). Today, 79\% of Oklahomans claim themselves as Christian (Pew Research Center, 2014). While there seems to be a close split between registered Christian Republicans (45\%) and Democrats (40\%), it is ideological belief that is striking, with only $19 \%$ of Christians having a liberal ideology (Pew Research Center, 2014). The reason for this may lie in Oklahoma's dominating religion, Evangelical Protestant. Evangelicals make up $47 \%$ of Christians in Oklahoma compared to only $20 \%$ in the entire nation. "Evangelicals are thought of as politically conservative, and there appears to be a strong distrust and alienation among evangelicals towards environmentalism and environmental concerns" (Wardekker et al., 2009). There is an interesting statistic that encapsulates what Gramsci meant when he discussed the nature of hegemony. When Oklahoma Christians were asked about environmental regulation, 52\% agreed stricter environmental laws and regulations were worth the cost compared to $42 \%$ of who were against such laws because it would cost too many jobs and hurt the economy (Pew Research Center, 2014). This statistic may suggest the majority, with conflicting views, consents to the dominant culture. Ives (2014) suggested one of Gramsci's central aspects of the inability of repressed groups to resist is they essentially "lack language of their own" (p. 78). Perhaps environmentally pro Oklahoma Christians lack their own voice.

\section{SOLUTIONS FOR EDUCATORS TO BE TRANSFORMATIVE}

\section{Solutions for Educators to Be Transformative}

"We are all weavers of the grand tapestry of history," (Figueres \& Rivett-Carnac, 2020). For many, the situation seems bleak and hopeless. As a society, we have accepted what the dominant culture in power have told us. We have come to believe our society cannot survive without our dependence on fossil fuels and on capitalism as we know it. We cannot abandon our politics or religious values because it could mean alienation. The task seems hopeless because it seems larger than us. Maxine Greene (1988) stated it so eloquently, providing inspiration:

to become different, of course, is not simply to will oneself to change. There is the question of being able to accomplish what one chooses to do. It is not only a matter of the capacity to choose; it is a matter of the power to act to attain one's purposes. We shall be concerned with intelligent choosing and yes, humane choosing, as we shall be with the kinds of conditions necessary for empowering persons to act on what they choose. It 
is clear enough that choice and action both occur within and by means of ongoing transactions with objective conditions and with other human beings.... Whatever is chosen and act upon must be grounded, at least to a degree, in an awareness of a world lived in common with others, a world that can be to some extend transformed. (p. 4)

There are several ways to take small actions to bring about transformation not only in our educational system, but in the communities we live: (a) knowing ourselves as educators, (b) finding our collective voice, (c) using softer language, and (d) connecting with allies in our communities.

\section{Knowing Ourselves as Educators}

It begins with us as educators. How often do we spend the time to engage in active reflection of our profession? We are caught up in the demands of our districts and administrators, ever pushing us to prepare students for the end of year standardized tests. Our administrators want to see weekly lesson plans that include minimum graded assessments per week and show we are staying on track with the state mandated curriculum. We are summoned to become sponsors of extracurricular activities and organizations for students. In the struggle to keep our heads above water, there is little time left for self-reflection in our practice. Perhaps our first task is to stop and evaluate how we have become part of the problem by not routinely reflecting on our personal values, morals, and ethics that make up our philosophy of education. We became teachers for a reason and began with a passionate belief we could change the world:

remembering ourselves and our power can lead to revolution but requires more than recalling a few facts. Re-remembering involves putting ourselves back together, recovering identity and integrity, reclaiming the wholeness of our lives. When we forget who we are we do not merely drop some data. We dis-member ourselves, with unhappy consequences for our politics, our work, our hearts. (Palmer, 2007, p. 21)

Paulo Freire (1998) was an ardent believer that educators should be engaged in selfreflection to develop a critical consciousness. He spoke of teachers as having the "ethical responsibility in the exercise of our profession" (Freire, 1998, p. 22). Reflection of ourselves as educators enables us to develop a consciousness about our practice. Freire (1998) called for educators to practice "a universal human ethic," where educators are not afraid to condemn those in power. In the issue of denying students the opportunities to an equitable science education, where do we see ourselves? What are the values, morals, and ethical beliefs that make up our individual educational philosophies? Are we living up to our philosophy, or have we consented to a dominate power with differing views than our own?

\section{Finding our Collective Voice}

Not only do we need to be continually empowered to choose ourselves, to create our identities within plurality; we need continually to make new promises and to act in our 
freedom to fulfill them, something we can never do meaningfully alone. (Greene, 1998, p. 51)

To borrow from Henry Giroux (1985), to be transformative, we must value ourselves as "intellectual professionals" who are experts in our field. Legislators fail to recognize educators as experts who know what is best for their students. Legislators do not have the background knowledge to understand child cognitive development, pedagogy, and curriculum the way we do as educators. As a group of intellectual professionals in education, we must take our power back and stand up against those who subvert their views and agendas that conflict with providing democratic educational freedoms. We must recognize this obstacle for what it is. As educators, we must create that space where we meet in the middle to discuss without judgments, to gain perspectives, and question. We must embrace our power as an intellectual profession and push back against those who devalue our profession.

\section{Using Softer Language}

Educators who challenge themselves to teach beyond the classroom setting, to move into the world sharing knowledge, learn a diversity of styles to convey information. This is one of the most valuable skills any teacher can acquire. Through vigilant practice we learn to use the language that can speak to the heart of the matter in whatever teaching setting we may find ourselves. (Hooks, 2003, p. 43)

Though we may be criticized by some who insist on strong, direct climate change language, we know our students and community. We are members of the same culture dependent upon the oil and gas industry for both state and personal survival. We understand "global warming and climate change" are fighting words. We also know we must remain respectful of our students whose parents work in the oil and gas industry. "Classrooms must be safe places, both emotionally and physically, for all students" (Mackenzie, 2020, p. 6).

The reason Wyoming educators were successful in getting an adaptation of the NGSS MSESS3-5 in their standards was because they spent time valuing what Wyomingites had to say and wanted (Edwards, 2017). Committee members said it was not easy because certain "buzz words" can provoke heated emotions. Despite this challenge, the committee was committed to preserve rigorous science, which meant presenting evidence of the combustion of fossil fuels contributing to global warming. Since Wyomingites were concerned with their glaciers melting, educators phrased standards to reflect the positive impact of decreasing carbon emissions meant cooler temperatures which in turn would increase glacier ice (Edwards, 2017). In the end, the Wyoming standard has a more palatable tone; it was accepted, and surprisingly, climate education is going well (Edwards, 2017).

Local environmentalists in Tulsa, Oklahoma, a city founded on the oil industry, understand the choice of words when working with government and business leaders. Tulsa has experienced more extreme weather conditions, including heavy downpours causing reoccurring 
flooding. Environmentalists know these conditions are a result of climate change but frame the issue in terms of "extreme weather conditions" that pose a threat to the community. As a result, they have a working relationship with the city to provide solutions that protect the community (Greenblatt, 2017).

\section{Connecting with Allies in Our Community}

We must remember as educators, we do not stop teaching once we leave the classroom. Education must extend into our communities. There are many opportunities to engage with our communities. Connecting with environmentalists, business leaders, politicians, and organizations with the same mission will provide us with a stronger voice to make a change. Although there are differing views among Christians towards climate change, Christians are concerned about the environment, especially how it affects the poor. Christian voices have the power to reach conservative politicians. We can collaborate with them (Wardekker et al., 2009). As indicated by the 2014 Pew Research Center survey of Oklahoma Christians, 52\% believe stricter environmental policies are worth the cost. There may be opportunities for us to provide workshops and educational materials on climate change and energy savings to Christian organizations who want to know more (Wardekker et al., 2009).

We must also create a space of dialogue with politicians and business leaders who hold differing ideologies. It is imperative we provide the education they need to understand the crisis we are facing. We need to make strong arguments for why providing opportunities for our students to analyze data and to develop positive solutions keeps them competitive with other American students.

\section{CONCLUSION}

Naming and understanding how the economic base, political, and religious constructs of the society determines what can and cannot be taught provides educators with the knowledge to act against the unethical denial of equitable science education. For educators living in states depending upon the oil and gas industry, we must remember our ethical and moral responsibilities for providing equitable educational opportunities for our students. We must find our voices and take back the power we have as an intellectual professional in education. However small of a step we take, it is a small step forward.

\section{A FINAL HOPE FOR OKLAHOMA}

Change is slowly happening across all educational issues in Oklahoma. In 2018, Oklahoma teachers took a stand for teacher pay, school funding, and classroom overcrowding by conducting a nine-day walkout. While other teachers across the U.S. also conducted walkouts, McGreal (2018) said Oklahoma was politically impacted the most. The Oklahoma teacher walkout put a crack in the Oklahoma Republican Party. Teachers ran for office and incumbent 
Republicans, who had voted against a teacher pay raise, either did not run for office again or lost their primaries (McGreal, 2018). Change is also occurring as the OAS-S come up for revision and approval in 2020. While Oklahoma middle schoolers were denied the opportunity to learn about human activities causing climate change in the 2014 OAS-S, the new revisions will include this scientific education (Martinez-Keel, 2020). As educators, we must embrace these small victories, continue to work towards others, and always hold space for the possibilities.

\section{REFERENCES}

Benedict XVI. (2014). The garden of God: Toward a human ecology. The Catholic University of America Press.

Brown, T. I. (2017, May 23). Donations, lobbying reflect influence of oil and gas industry. Oklahoma Watch. https://oklahomawatch.org/2017/05/23/donations-lobbyingreflect-influence-of-oil-and-gas-industry/

Burton, I. (2014, July 11). Pope Francis's radical environmentalism. Exploiting the earth "is our sin," the pontiff says. The Atlantic.

https://www.theatlantic.com/international/archive/2014/07/pope-franciss-radicalrethinking-of-environmentalism/374300/

Chen, J. (2019, June 25). Top 6 oil-producing states. Investopedia.

https://www.investopedia.com/financial-edge/0511/top-6-oil-producing-states.aspx

Chesapeake Energy. (2019). Fueling the lives of Oklahomans [Fact sheet].

http://www.chk.com/documents/operations/state-fact-sheets.pdf

Crosby, A. W. (2010). Ecological imperialism: The biological expansion of Europe. Cambridge University Press. (Original work published 1986)

Devon. (n.d.). About us. https://www.devonenergy.com/about-us

Dimitriadis, G. \& Kamberelis, G. (2006). Theory for education. Routledge.

Di Piero, D. (2015, April 13). Top 5 industries in Oklahoma: Which parts of the economy are the strongest? NewsMax. https://www.newsmax.com/FastFeatures/industries-inoklahoma-economy/2015/04/13/id/638098/

Edwards, M. (2017, February 24). Taking a look at Wyoming science standards, then and now. Wyoming Public Media. https://www.wyomingpublicmedia.org/post/taking-lookwyoming-science-standards-then-and-now\#stream/0

Environmental and Energy Institute. (2015, August 5). Fact sheet-Timeline of progress made in President Obama's climate action plan. https://www.eesi.org/papers/view/fact-sheettimeline-progress-of-president-obama-climate-action-plan

Environmental Protection Agency. (2016). What climate change means for Oklahoma (EPA 430-F-16-038) [PDF file]. https://www.investopedia.com/financial-edge/0511/top-6-oilproducing-states.aspx 
Figueres, C. \& Rivett-Carnac, T. (2020). The future we choose: Surviving the climate crisis. Alfred A. Knopf.

Forbes. (2019, December 17). America's largest private companies. Forbes.

https://www.ok.gov/elections/documents/20190115\%20 \%20Registration\%20By\%20County\%20(vr2420).pdf

Francis. (2015). Laudato si': On care for our common home. [Encyclical letter]. https://laudatosi.com/watch

Freire, P. (1998). Pedagogy of freedom: Ethics, democracy, and civic courage. (P. Clarke, Trans.). Rowman and Littlefield Publishers, Inc.

Gaddie, R. K. (n.d). Republican party. The Encyclopedia of Oklahoma history and culture. Retrieved March 17, 2020, from

https://www.okhistory.org/publications/enc/entry.php?entry=RE030

Gill, V. (2020, February 24). Australia fires were far worse than prediction. BBC News.

https://www.bbc.com/news/science-environment-51590080

Giroux, H. A. (1985). Teachers as transformative intellectuals. Social Education, 49(5), 376-379.

Global Change. (n.d.). Sea level rise. https://www.globalchange.gov/browse/indicators/globalsea-level-rise

Goble, D. (n.d.). Government and Politics. The Encyclopedia of Oklahoma history and culture.

Retrieved March 17, 2020 from

https://www.okhistory.org/publications/enc/entry.php?entry=G0018

Greenblat, A. (2017). The city preparing for climate change without saying the words.

Governing. https://www.governing.com/topics/transportation-infrastructure/gov-

tulsa-climate-change-resilience-adaptation-flooding.html

Greene, M. (1988). The dialectic of freedom. Teachers College Press.

Halter, C. (2019, July 11). Requiring schools to teach climate change risks backlash in

Oklahoma. State Impact. https://stateimpact.npr.org/oklahoma/2019/07/11/requiringschools-to-teach-climate-change-risks-backlash-in-oklahoma/

Hooks, B. (2003). Teaching community: A pedagogy of hope. Routledge.

House State Legislature. (n.d.). House of representatives: Capitol tours [Description].

https://www.okhouse.gov/information/capitoltours.aspx

Ives, P. (2004). Language and hegemony in Gramsci. Pluto Press.

Krehbiel, R. (2016, July 4). Democrat or Republican, Oklahoma has always been conservative.

Tulsa World. https://www.tulsaworld.com/news/local/government-and-

politics/democrat-or-republican-oklahoma-has-always-been-

conservative/article 8039ed1e-5184-51cf-a3b4-eda538f4559f.html

Laurent, E. (2020). The new environmental economics. Polity Press.

Mackenzie, A. N. (2020). Social justice in the science classroom. The Science Teacher, 87(7), 6-

7. 
Martinez-Keel, N. (2020, February 29). Oklahoma school standards could add biological evolution, expand on climate change. The Oklahoman.

https://oklahoman.com/article/5656205/oklahoma-school-standards-could-addbiological-evolution-expand-on-climate-change

Marx, K. (1887/2010). Capital vol 1. Pacific Publishing Studio.

McDonnell, T. (2019, January 24). Climate change creates a new migration crisis for Bangladesh. National Geographic.

https://www.nationalgeographic.com/environment/2019/01/climate-change-drivesmigration-crisis-in-bangladesh-from-dhaka-sundabans/

McGreal, C. (2018, September 7). The teacher revolt reshaping U.S. politics. The Guardian. https://www.theguardian.com/us-news/2018/sep/07/teachers-oklahoma-activism-uspolitics-strike-walkout

Mooney, C. (2014, May 16). AUDIO: Why Oklahoma lawmakers don't want kids to learn about climate. Mother Jones.

https://www.motherjones.com/environment/2014/05/oklahoma-climate-scienceeducation-denial/

NASA https://earthobservatory.nasa.gov/images/146322/antarctica-melts-under-its-hottestdays-on-record

NASA (2019, April 25). Antarctica's effect on sea level rise in coming centuries [Press release]. https://climate.nasa.gov/news/2869/antarcticas-effect-on-sea-level-rise-in-comingcenturies/

National Research Council (NRC) (2012). A framework for K-12 science education: Practices, crosscutting concepts, and core ideas. National Academies Press.

http://www.nap.edu/catalog/13165/a-framework-for-k-12-science-educationpractices-crosscutting-concepts

National Basketball Association. (n.d.). The official site of the Oklahoma City Thunder. https://www.nba.com/thunder/

NGSS Lead States. (2013). Next generation science standards: For states, by states. National Academies Press. Retrieved from www.nextgenscience.org

NGSS Lead States. (2013). Next generation science standards: For states by states (Appendix FScience and engineering practices in the NGSS) [PDF file.].

https://www.nextgenscience.org/sites/default/files/resource/files/Appendix\%20F\%20 \%20Science\%20and\%20Engineering\%20Practices\%20in\%20the\%20NGSS\%20\%20FINAL\%20060513.pdf

Oklahoma Climatological Survey. (2020, April 1). Spring steps forward during March. https://climate.ok.gov/index.php/site/page/news 
Oklahoma State Election Board. (2019). MESA: Current registration by county.

https://www.ok.gov/elections/documents./20190115\%20-

\%20Registration\%20By\%20County\%20(vr2420).pdf

Oklahoma State Department of Education. (2013). Oklahoma academic standards for science. Oklahoma City, OK: Oklahoma State Department of Education.

http://sde.ok.gov/sde/sites/ok.gov.sde/files/OAS Science Standards 3-2-15.pdf

Oklahoma State Legislature. (2020). House of representatives: Capitol tours.

https://www.okhouse.gov/information/capitoltours.aspx

Palmer, P. J. (2010). The courage to teach (10 ${ }^{\text {th }}$ ed.). Jossey Bass.

Pew Research Center. (2014). U. S. religious landscape study.

https://www.pewforum.org/religious-landscape-study/

Pew Research Center. (2019, October 7). In their own words: Behind Americans' views of 'socialism' and 'capitalism.' https://www.people-press.org/2019/10/07/in-their-ownwords-behind-americans-views-of-socialism-and-capitalism/

Seifert, K. \& Sutton, R. (2011). Educational psychology ( ${ }^{\text {rd }}$ ed.). Global Text.

Stebbins, S. (2018 August 27). These are the largest industries in every state. USA Today. https://www.usatoday.com/story/money/economy/2018/08/27/largest-industry-ineach-state/37585051/

Wallace-Wells, David. (2020, February 26). What Coronavirus teaches us about climate change. Intelligencer. https://www.globalchange.gov/browse/indicators/global-sealevel-rise

Wardekker, J. A., Petersen, A. C., \& van der Sluijs, J. P. (2009). The ethics and public perception of climate change: Exploring the Christian voices in the US public debate. Global Environmental Change, 19, 512-521.

Weubbles, D. J. Fahey, D. W., Hibbard, K. A., DeAngelo, B., Doherty, S., Hayhoe, K., Horton, R. Kossin, J.P., Taylor, P. C., Waple, A. M. \& Weaver, C.P. (2017). Executive summary of the climate science special report: Fourth national climate assessment, volume I. Global Change Research Program.

Wyoming State Board of Education. (2016). Wyoming science content and performance standards. https://edu.wyoming.gov/educators/standards/science 